\title{
The Effects of Glyphosate on the Growth of Birdsfoot Trefoil (Lotus corniculatus) and Its Interaction with Different Phosphorus Contents in Soil
}

\author{
A. Clua ${ }^{1}$, M. Conti ${ }^{1} \&$ J. Beltrano ${ }^{1,2}$ \\ ${ }^{1}$ Facultad de Ciencias Agrarias y Forestales, UNLP, Argentina \\ ${ }^{2}$ Comisión de Investigaciones Científicas de la Provincia de Buenos Aires (CICBA), Argentina \\ Correspondence: J. Beltrano, Comisión de Investigaciones Científicas de la Provincia de Buenos Aires (CICBA), \\ Argentina. E-mail: jbeltrano@agro.unlp.edu.ar
}

\author{
Received: February 14, 2012 Accepted: March 5, 2012 Online Published: June 6, 2012 \\ doi:10.5539/jas.v4n7p208 URL: http://dx.doi.org/10.5539/jas.v4n7p208
}

\begin{abstract}
Glyphosate residues from applications or exuded by roots of treated crops and by senescing weeds could be absorbed by new crops. The aim of this work was to study the effect of glyphosate in soil on the growth of Lotus corniculatus and its interaction with phosphorus. A completely randomized $3 \times 4$ factorial design was used for the experiment, with 3 levels of phosphorus $(0,100$, and $200 \mathrm{ppm})$ and 4 of glyphosate $(0 ; 0.5 ; 1.0$, and 2.0 times the recommended dosage, $4 \mathrm{~L}$. ha ${ }^{-1}$ ), amended to soil. Glyphosate residues decreased growth parameters, chlorophyll and protein contents, and membrane stability. Glyphosate effect was increased by the greater availability of phosphorus, so there was a significant interaction between glyphosate and phosphorus. The findings of this study provide evidence of the detrimental effect of glyphosate present in soil as well as its remobilization through the presence of additional phosphorus in soil.
\end{abstract}

Keywords: Lotus corniculatus, glyphosate-phosphorus interaction

\section{Introduction}

The application of herbicides is a common practice to control weed growth in crops. Glyphosate is one of the most widely used herbicides, known for its effective control of weeds, inactivation in soil, and low mammalian toxicity (Busse et al., 2001). The use of glyphosate in Argentina has increased due to low or no-till agriculture and the use of genetically modified glyphosate-tolerant crops (Blackburn \& Boutin, 2003). In 2010, 16 million hectares in Argentina were sown with Roundup Ready (RR) soybean cultivars, and 150 million liters of glyphosate were used (Pengue, 2000). This increase in the area of soybean production caused livestock activity to be displaced to less suitable areas.

Birdsfoot trefoil (Lotus corniculatus L.) is a valuable forage crop because it adapts well to less suitable growing areas where Gramineae predominate and where alfalfa and others legumes do not grow (Agnusdei, 1991; Leon \& Bertiller, 1982). It is therefore, the most suitable legume for enhancing soil nitrogen, and is also highly digestible, with a forage quality comparable to alfalfa (Medicago sativa L.) and white clover (Trifolium repens L.) (Beuselinck \& Grant, 1995).

Glyphosate (N-phosphonomethyl glycine) is a systemic non-selective herbicide that controls most annual and perennial plants by inhibiting the activity of 5-enolpyruvyl-shikimic acid-3 phosphate synthase (EPSPS). It thereby blocks the synthesis of the aromatic amino acids phenylalanine, tyrosine, and tryptophan, which are essential in protein synthesis and in the secondary metabolism of plants. Inhibition of EPSPS causes a decrease in growth, mainly in metabolically active tissues such as immature leaves, young stems and root apices (Grossbard \& Atkinson, 1985).

Many studies have shown the presence of glyphosate in soils as a result of its application in weed treatments prior to the sowing of pasture or other crops and subsequent leaching from cultivated areas (Kurincic et al., 2002; Rueppel et al., 1977; Nomura \& Hilton, 1977).

Soil retention limits the glyphosate interaction with roots. However some studies have shown that immobilized glyphosate can be released from the soil and consequently percolates or leaches towards watercourses (Piccolo et al., 1994). Moreover, Neumann et al. (2006) demonstrated that glyphosate can be exuded by senescing weed roots and absorbed by newly planted crops, causing toxicity to plants and a reduction in growth. Pline et al. 
(2002) found that, in cotton plants, the fresh weights of root and aerial parts were reduced at non-lethal glyphosate concentrations. Under the same conditions, glyphosate inhibited the development of lateral roots, which appeared shorter and were surrounded by a thick layer of necrotic cells at their apices. Torres et al. (2003) also observed a reduction in the growth and length of lateral roots in soybean plants. The same effect was observed in pepper plants (Ronco et al., 2008).

Phosphorus fertilization improves the implantation and competitive ability of legumes. L. corniculatus has been shown to respond better to lower doses of phosphorus than other legume species, such as Trifolium pratense (Ayala Torales et al., 1992a: Ayala Torales et al., 1992b).

The glyphosate molecule, due to the methylphosphonic group it contains, can compete with inorganic phosphates for soil adsorption sites, giving rise to a glyphosate-phosphorus interaction in soils (McBride \& Kung, 1989; Dion et al., 2001; Gimsing \& Boggaard, 2001, 2002, 2004, Bott et al., 2011).

The glyphosate - phosphorus interaction is affected by different factors related to phosphorus and the glyphosate molecule. Several works describe the factors influencing glyphosate adsorption by soils or clays: $\mathrm{pH}$ (Nomura \& Hilton, 1977), cation exchange capacity (CEC); clay type and content (Glass, 1987); the presence of iron and aluminum amorphous oxides and organic matter (Morillo et al., 2000, Bott et al., 2011) and that of iron and aluminum oxides (Prata et al., 2000; Gerritse et al., 1996). Phosphorus adsorption capacity also depends on physical and chemical soil features such as regulatory phosphorus capacity (Beckett and White, 1964); clay content (Fox \& Kamprath, 1970), pH (Parfitt, 1977; Holford \& Patrick, 1979) and organic matter (Bolaño et al., 1984).

De Jonge et al. (2001) demonstrated that different levels of phosphate ions in soils affected glyphosate adsorption, such that glyphosate adsorption is reduced in soils with higher phosphate content, thus enhancing herbicide mobility and affecting crop growth.

However limited and contradictory information has been published regarding the effects of glyphosate-phosphorus interaction in soil, on forage plant growth. The aim of this work was to study the effect of glyphosate in soil on the growth of Lotus corniculatus and its interaction with phosphorus.

\section{Materials and Methods}

\subsection{Growth Conditions}

The experiment was conducted in natural light and temperature conditions in La Plata, Argentina $\left(34^{\circ} 54^{\prime} \mathrm{S}, 57^{\circ}\right.$ $\left.55^{\prime} \mathrm{W}\right)$.

L. corniculatus seeds were sown in $3 \mathrm{~L}$ plastic pots at a depth of $1 \mathrm{~cm}$. The substrate used in this study was a vertic argiudoll soil ( $\mathrm{pH} 5.5 ; \mathrm{EC}_{\mathrm{e}}, 6.1 \mathrm{dS} / \mathrm{m}$; total P $12 \mathrm{mg} \cdot \mathrm{kg}^{-1}$; organic matter $3.5 \%$; total C $2.0 \%$; total N 0.24 $\%$, clay $27 \%$ and CEC 32 meq. $\left.100 \mathrm{~g}^{-1}\right)$.

Before sowing, glyphosate (RoundUp ${ }^{\mathrm{TM}} ; 360 \mathrm{~g}$ isopropylamine salt of glyphosate $\mathrm{L}-1$ ) was added to the substrate to reach concentrations of $0(\mathrm{G} 0) ; 0.5(\mathrm{G} 1=3.15 \mu \mathrm{M}) ; 1.0_{-}(\mathrm{G} 2=6.32 \mu \mathrm{M})$ and $2.0(\mathrm{G} 3=12.64 \mu \mathrm{M})$ times the recommended dosage to be applied in fields (equivalent to $4 \mathrm{~L}$ of commercial product containing $36 \%$ a.i. $\mathrm{ha}^{-1}$ ). The necessary amount of herbicide was mixed with talc as an inert substrate, dried at room temperature, then macerated and added to the previously determined volume of soil. In additions, $\mathrm{PO}_{4} \mathrm{H}_{2} \mathrm{~K}$ was added to the substrate to reach concentrations of 12ppm (P0): P content in soil, $100 \mathrm{ppm}(\mathrm{P} 1)$ and $200 \mathrm{ppm}(\mathrm{P} 2)$.

The plants were watered in order to avoid leaching and so as to maintain the soil water potential at field capacity $(\psi=-0.03 \mathrm{MPa})$. The treatments were: (a) control, plants without the incorporation of phosphorus nor of glyphosate (P0G0); (b) no phosphorus and $3.15 \mu \mathrm{M}$ glyphosate (P0G1); (c) no phosphorus and $6.32 \mu \mathrm{M}$ glyphosate (P0G2); (d) no phosphorus and $12.64 \mu \mathrm{M}$ glyphosate (P0G3); (e) $100 \mathrm{ppm}$ P and no glyphosate (P1G0); (f) $100 \mathrm{ppm} \mathrm{P}$ and $3.15 \mu \mathrm{M}$ glyphosate (P1G1); (g) $100 \mathrm{ppm}$ P and $6.32 \mu \mathrm{M}$ glyphosate (P1G2); (h) 100 ppm P and $12.64 \mu \mathrm{M}$ glyphosate (P1G3); (i)200 ppm P and no glyphosate (P2G0); (j) $200 \mathrm{ppm} \mathrm{P}$ and $3.15 \mu \mathrm{M}$ glyphosate (P2G1); (k) $200 \mu p m$ P and $6.32 \mu \mathrm{M}$ glyphosate (P2G2); (1) $200 \mathrm{ppm} \mathrm{P}$ and $12.64 \mu \mathrm{M}$ glyphosate (P2G3).

\subsection{Parameters Measured}

Ten plants were harvested per treatment at three times during the experimental period 110,140 and 170 days after sowing (DAS) and growth parameters were determined.

\subsubsection{Growth Parameters}

At harvest, the following were measured: plant height; leaf area per plant (using a model Li-3000 leaf area meter; LICOR, Lincoln, NE, USA); root and aerial dry weights (RDW and ADW, respectively), obtained by drying the plant matter in an oven at $80^{\circ} \mathrm{C}$ until their weight became constant); and the length of regrowth stems. 


\subsubsection{Chlorophyll and Protein Contents of Leaves}

At the end of experimental period, chlorophyll content was determined on one leaf disc $(1 \mathrm{~cm}$ diameter $)$ per plant, using Morn and Porath's (1980) methodology. At the same time, protein content was determined using five leaf discs (1 cm diameter) per plant according to Bradford's (1976) methodology, with bovine serum albumin as the standard. Data were expressed as $\mu \mathrm{g}$ chlorophyll $\mathrm{cm}^{-2}$ and $\mu \mathrm{g}$ protein $\mathrm{cm}^{-2}$, respectively.

\subsubsection{Cell Membrane Stability (CMS) Determination in Leaves and Roots}

At the end of the experimental period, CMS was determined in $500 \mathrm{mg}$ of leaves and roots per treatment. The leaves and roots were washed with deionized water, and were incubated in deionized water at room temperature, according to Sullivan and Ross's (1979) methodology, and the conductivity was determined using a DIGICOND IV Conductimeter (Luftman Co., Argentina). CMS was determined using the following equation:

$$
\% \mathrm{CMS}=(1-(\mathrm{T} 1 / \mathrm{T} 2)) /(1-(\mathrm{C} 1 / \mathrm{C} 2)) * 100
$$

$\mathrm{C}$ and $\mathrm{T}$ refer to the conductivity of the control and treated samples, respectively. $\mathrm{C} 1$ and $\mathrm{T} 1$ represent the electrolyte leakage $\left(\mathrm{dS} \mathrm{m}^{-1}\right)$ after incubating the sample at $25{ }^{\circ} \mathrm{C}$ for 4 hours, and $\mathrm{C} 2$ and $\mathrm{T} 2$ represent the total electrolyte concentration measured after heating the sample in boiling water for 60 minutes and cooling it to room temperature.

\subsection{Statistical Analysis}

The experiment followed a randomized factorial $3 \times 4$ design, with three phosphorus levels (P0, P1, and P2) and four glyphosate levels (G0, G1, G2, and G3). All data were analyzed using Analysis of Variance (ANOVA). Tukey's test $(P<0.05)$ was used to evaluate differences between treatments and means of interaction, using SigmaStat 3.5 software (Systat Software, Inc., San Jose, CA, USA). The replicates number was 10.

\section{Results}

\subsection{Growth Parameters}

At 110 days after sowing, plants grown with glyphosate showed lower growth parameters than control plants. Moreover, phosphorus treatments increased growth parameters, and glyphosate $\mathrm{x}$ phosphorus interaction was positive (Table 1). The same trend was observed 140 and 170 days after sowing (Table 2 and Table 3, respectively).

Table 1. Effect of phosphorus and glyphosate addition to soil, on root and aerial dry weight (RDW and ADW), leaf area (LA) and plant height (PH) on Lotus corniculatus plants, 110 days after sowing

\begin{tabular}{|c|c|c|c|c|}
\hline Treatment* & RDW (g) & ADW (g) & $\mathrm{LA}\left(\mathrm{cm}^{-2}\right)$ & P H $(\mathrm{cm})$ \\
\hline P0 G0 & $6.7 \mathrm{c}$ & $4.0 \mathrm{~b}$ & $850 \mathrm{c}$ & $28.5 \mathrm{~b}$ \\
\hline P0 G1 & $6.7 \mathrm{c}$ & $4.0 \mathrm{~b}$ & $650 \mathrm{~d}$ & $25.0 \mathrm{~b}$ \\
\hline P0 G2 & $5.5 \mathrm{~d}$ & $3.0 \mathrm{c}$ & $550 \mathrm{e}$ & $23.0 \mathrm{bc}$ \\
\hline P0 G3 & $4.8 \mathrm{e}$ & $2.8 \mathrm{c}$ & $500 \mathrm{e}$ & $19.5 \mathrm{c}$ \\
\hline P1 G0 & $7.2 \mathrm{~b}$ & $5.7 \mathrm{a}$ & $1100 \mathrm{~b}$ & $32.0 \mathrm{a}$ \\
\hline P1 G1 & $7.1 \mathrm{~b}$ & $5.6 \mathrm{a}$ & $1000 \mathrm{~b}$ & $27.5 \mathrm{~b}$ \\
\hline P1 G2 & $4.2 \mathrm{f}$ & $3.6 \mathrm{~b}$ & $600 \mathrm{de}$ & $21.5 \mathrm{c}$ \\
\hline P1 G3 & $4.0 \mathrm{f}$ & $2.8 \mathrm{c}$ & $550 \mathrm{e}$ & $20.0 \mathrm{c}$ \\
\hline P2 G0 & $8.2 \mathrm{a}$ & $6.1 \mathrm{a}$ & $1375 a$ & $33.5 \mathrm{a}$ \\
\hline P2 G1 & $6.8 \mathrm{c}$ & $5.8 \mathrm{a}$ & $1175 \mathrm{~b}$ & $27.5 \mathrm{~b}$ \\
\hline P2 G2 & $4.9 \mathrm{e}$ & $4.0 \mathrm{~b}$ & $725 \mathrm{c}$ & $22.0 \mathrm{c}$ \\
\hline P2 G3 & $3.7 \mathrm{f}$ & $2.0 \mathrm{~d}$ & $575 \mathrm{e}$ & $18.5 \mathrm{c}$ \\
\hline \multicolumn{5}{|l|}{ Significance } \\
\hline $\mathrm{P}$ & ** & $* *$ & $* *$ & $* *$ \\
\hline G & ** & $* *$ & $* *$ & * \\
\hline$P \times G$ & * & * & $* *$ & $* *$ \\
\hline
\end{tabular}

*P0G0, without incorporation of phosphorus and glyphosate; P0G1, without $\mathrm{P}+3.15 \mu \mathrm{M}$ glyphosate; P0G2, without $\mathrm{P}+6.32 \mu \mathrm{M}$ glyphosate; P0G3, without $\mathrm{P}+12.64 \mu \mathrm{M}$ glyphosate; P1G0, $100 \mu \mathrm{ppm} \mathrm{P}$ without glyphosate: P1G1, 100 ppm P + 3.15 $\mu \mathrm{M}$ glyphosate; P1G2, 100 ppm P + 6.32 $\mu \mathrm{M}$ glyphosate; P1G3, 100 ppm $\mathrm{P}+12.64 \mu \mathrm{M}$ glyphosate; P2G0, $200 \mathrm{ppm}$ P without glyphosate; P2G1, 200 ppm P + $3.15 \mu \mathrm{M}$ glyphosate; P2G2, 200 ppm P + 6.32 $\mu \mathrm{M}$ glyphosate; P2G3, 200 ppm P + $12.64 \mu \mathrm{M}$ glyphosate. Mean values followed by the same lower-case letter within each column are not significantly different $(P>0.05)$. ns, *,**: non-significant, or significant at $P \leq 0.05$ or 0.01 , respectively. 
The treatments with the highest glyphosate levels, P0G2 and P0G3, reduced root growth (RDW) significantly - by $18 \%$ and $28 \%$, respectively - compared with the control. Conversely, phosphorus treatments enhanced RDW significantly compared with the control, to the order of $7 \%$ for P1G0 and $22 \%$ for P2G0. The glyphosate-phosphorus interaction was significant and RDW was reduced as phosphorus levels increased, to the order of $17 \%$ P1G3 and $23 \%$ for P2G3, compared with P0G3 (Table 1).

The ADW was reduced by glyphosate and enhanced by phosphorus. The treatments with the highest glyphosate levels, P0G2 and P0G3, reduced ADW significantly compared with the control, to the order of $25 \%$ and $30 \%$, respectively. There were no differences for P0G1. Phosphorus treatments significantly increased the ADW: by $42 \%$ for P1G0 and $52 \%$ for P2G0. The glyphosate-phosphorus interaction for ADW was significant. The increase in phosphorus levels caused a significant reduction in ADW, through the increase of glyphosate desorption levels, comparing P1 and P2 with P0 phosphorus levels (Table 1).

Leaf area was affected negatively by glyphosate but positively by phosphorus. All glyphosate treatments reduced leaf area significantly compared with the control. In this regard, there were no differences between P0G2 and P0G3. With respect to phosphorus treatments, P1 and P2 showed an enhanced leaf area, to the order of $29 \%$, and $61 \%$, respectively, compared with the control. The glyphosate-phosphorus interaction was significant. The reduction in leaf area was greater at P1 and P2 levels, compared with P0, by the glyphosate increased from G1 to G2 (Table 1).

All glyphosate treatments had a significant effect on plant height, which was reduced by $12 \%$ for P0G1, 20\% for P0G2, and 32\% for P0G3, compared with the control treatment. Meanwhile, phosphorus treatments P1G0 and P2G0 enhanced plant height significantly compared with the control. The glyphosate-phosphorus interaction was also significant, and increased phosphorus levels led to plant height being more affected by glyphosate, mainly at the P2G3 level (Table 1). Similar results were obtained at 140 and 170 days after sowing (Table 2 and Table 3 , respectively).

Table 2. Effect of phosphorus and glyphosate addition to soil, on root and aerial dry weight (RDW and ADW), leaf area (LA) and plant height (PH) on Lotus corniculatus plants, 140 days after sowing

\begin{tabular}{lcccc}
\hline \multicolumn{1}{c}{ Treatment } & RDW $(\mathrm{g})$ & ADW $(\mathrm{g})$ & LA $\left(\mathrm{cm}^{2}\right)$ & PH $(\mathrm{cm})$ \\
\hline P0G0 & $7.6 \mathrm{~b}$ & $5.3 \mathrm{~b}$ & $1105 \mathrm{c}$ & $37.1 \mathrm{~b}$ \\
P0G1 & $6.9 \mathrm{c}$ & $5.2 \mathrm{~b}$ & $845 \mathrm{~d}$ & $32.5 \mathrm{~b}$ \\
P0G2 & $4.9 \mathrm{e}$ & $3.2 \mathrm{c}$ & $590 \mathrm{e}$ & $24.6 \mathrm{c}$ \\
P0G3 & $4.2 \mathrm{e}$ & $2.6 \mathrm{~d}$ & $465 \mathrm{f}$ & $19.0 \mathrm{c}$ \\
& & & & \\
P1G0 & $8.1 \mathrm{~b}$ & $7.5 \mathrm{a}$ & $1436 \mathrm{~b}$ & $41.5 \mathrm{a}$ \\
P1G1 & $7.9 \mathrm{~b}$ & $7.4 \mathrm{a}$ & $1290 \mathrm{c}$ & $35.7 \mathrm{~b}$ \\
P1G2 & $4.9 \mathrm{e}$ & $4.7 \mathrm{~b}$ & $790 \mathrm{~d}$ & $23.8 \mathrm{c}$ \\
P1G3 & $4.8 \mathrm{e}$ & $3.7 \mathrm{c}$ & $618 \mathrm{e}$ & $21.1 \mathrm{c}$ \\
& & & & \\
P2G0 & $9.3 \mathrm{a}$ & $8.0 \mathrm{a}$ & $1768 \mathrm{a}$ & $43.4 \mathrm{a}$ \\
P2G1 & $7.7 \mathrm{~b}$ & $7.6 \mathrm{a}$ & $1503 \mathrm{~b}$ & $35.6 \mathrm{~b}$ \\
P2G2 & $5.6 \mathrm{~d}$ & $4.7 \mathrm{~b}$ & $870 \mathrm{~d}$ & $24.6 \mathrm{c}$ \\
P2G3 & $4.0 \mathrm{e}$ & $2.4 \mathrm{~d}$ & $410 \mathrm{f}$ & $20.9 \mathrm{c}$
\end{tabular}

\section{Significance}

\begin{tabular}{lllll}
$\mathrm{P}$ & $* *$ & $* *$ & $* *$ & $* *$ \\
$\mathrm{G}$ & $* *$ & $* *$ & $* *$ & $*$ \\
$\mathrm{PxG}$ & $*$ & $*$ & $* *$ & $* *$ \\
\hline
\end{tabular}

*P0G0, without incorporation of phosphorus and glyphosate; P0G1, without $\mathrm{P}+3.15 \mu \mathrm{M}$ glyphosate; P0G2, without $\mathrm{P}+6.32 \mu \mathrm{M}$ glyphosate; P0G3, without $\mathrm{P}+12.64 \mu \mathrm{M}$ glyphosate; P1G0, $100 \mathrm{ppm} \mathrm{P}$ without glyphosate: P1G1, 100 ppm P + 3.15 $\mu \mathrm{M}$ glyphosate; P1G2, 100 ppm P + 6.32 $\mu \mathrm{M}$ glyphosate; P1G3, 100 ppm $\mathrm{P}+12.64 \mu \mathrm{M}$ glyphosate; P2G0, $200 \mathrm{ppm}$ P without glyphosate; P2G1, $200 \mathrm{ppm}$ P + $3.15 \mu \mathrm{M}$ glyphosate; P2G2, 200 ppm P + $6.32 \mu \mathrm{M}$ glyphosate; P2G3, 200 ppm P + $12.64 \mu \mathrm{M}$ glyphosate. Mean values followed by the same lower-case letter within each column are not significantly different $(P>0.05)$. ns, *,**: non-significant, or significant at $P \leq 0.05$ or 0.01 , respectively. 
Table 3. Effect of phosphorus and glyphosate addition to soil, on root and aerial dry weight (RDW and ADW), leaf area (LA) and plant height ( $\mathrm{PH})$ on Lotus corniculatus plants, 170 days after sowing

\begin{tabular}{lcccc}
\hline Treatment & RDW $(\mathrm{g})$ & ADW $(\mathrm{g})$ & LA $\left(\mathrm{cm}^{2}\right)$ & PH $(\mathrm{cm})$ \\
\hline P0G0 & $6.4 \mathrm{c}$ & $5.6 \mathrm{~b}$ & $1160 \mathrm{~d}$ & $39.5 \mathrm{~b}$ \\
P0G1 & $5.4 \mathrm{c}$ & $5.4 \mathrm{~b}$ & $887 \mathrm{e}$ & $34.1 \mathrm{~b}$ \\
P0G2 & $2.7 \mathrm{e}$ & $1.9 \mathrm{~d}$ & $354 \mathrm{fg}$ & $24.8 \mathrm{c}$ \\
P0G3 & $2.4 \mathrm{e}$ & $1.4 \mathrm{~d}$ & $280 \mathrm{~g}$ & $18.5 \mathrm{~d}$ \\
& & & & \\
P1G0 & $7.8 \mathrm{~b}$ & $7.8 \mathrm{a}$ & $1508 \mathrm{~b}$ & $44.2 \mathrm{a}$ \\
P1G1 & $7.1 \mathrm{~b}$ & $7.6 \mathrm{a}$ & $1360 \mathrm{c}$ & $38.0 \mathrm{~b}$ \\
P1G2 & $4.0 \mathrm{~d}$ & $3.9 \mathrm{c}$ & $730 \mathrm{e}$ & $23.6 \mathrm{c}$ \\
P1G3 & $4.1 \mathrm{~d}$ & $3.0 \mathrm{c}$ & $500 \mathrm{f}$ & $21.1 \mathrm{~cd}$ \\
& & & & \\
P2G0 & $9.8 \mathrm{a}$ & $8.4 \mathrm{a}$ & $1856 \mathrm{a}$ & $46.2 \mathrm{a}$ \\
P2G1 & $8.7 \mathrm{~b}$ & $8.0 \mathrm{a}$ & $1580 \mathrm{~b}$ & $37.9 \mathrm{~b}$ \\
P2G2 & $5.1 \mathrm{c}$ & $4.2 \mathrm{c}$ & $810 \mathrm{e}$ & $24.5 \mathrm{c}$ \\
P2G3 & $3.5 \mathrm{~d}$ & $2.0 \mathrm{~d}$ & $441 \mathrm{f}$ & $20.4 \mathrm{~cd}$
\end{tabular}

$\begin{array}{lllll}\text { Significance } & & & & \\ \mathrm{P} & * * & * * & * * & * * \\ \mathrm{G} & * * & * * & * * & * \\ \mathrm{P} \times \mathrm{G} & * & * & * * & * *\end{array}$

*P0G0, without incorporation of phosphorus and glyphosate; P0G1, without $\mathrm{P}+3.15 \mu \mathrm{M}$ glyphosate; P0G2, without $\mathrm{P}+6.32 \mu \mathrm{M}$ glyphosate; P0G3, without $\mathrm{P}+12.64 \mu \mathrm{M}$ glyphosate; P1G0, $100 \mu \mathrm{ppm} \mathrm{P}$ without glyphosate: P1G1, 100 ppm P + 3.15 $\mu \mathrm{M}$ glyphosate; P1G2, 100 ppm P + 6.32 $\mu \mathrm{M}$ glyphosate; P1G3, 100 ppm $\mathrm{P}+12.64 \mu \mathrm{M}$ glyphosate; $\mathrm{P} 2 \mathrm{G} 0,200$ ppm P without glyphosate; $\mathrm{P} 2 \mathrm{G} 1,200$ ppm P $+3.15 \mu \mathrm{M}$ glyphosate; P2G2, 200 ppm P + 6.32 $\mu \mathrm{M}$ glyphosate; P2G3, 200 ppm P + $12.64 \mu \mathrm{M}$ glyphosate. Mean values followed by the same lower-case letter within each column are not significantly different $(P>0.05)$. ns, *, **: non-significant, or significant at $P \leq 0.05$ or 0.01 , respectively.

Branch numbers were enhanced significantly by the higher phosphorus levels (P2G0) and unaffected by glyphosate treatments. Meanwhile, the length of regrowth stems was reduced significantly by the higher glyphosate level (P0G3) and unaffected by phosphorus treatments. Glyphosate-phosphorus interaction was not significant (data not shown).

\subsection{Chlorophyll and Protein Contents of Leaves}

Chlorophyll content was significantly reduced by glyphosate. P0G1 reduced chlorophyll content by $12 \%$, P0G2 by $53 \%$, and $\mathrm{P} 0 \mathrm{G} 3$ by $77 \%$ compared with the control. Plants with phosphorus treatments showed an increase in chlorophyll content, to an order of $41 \%$ for $\mathrm{P} 1 \mathrm{G} 0$ and $94 \%$ for $\mathrm{P} 2 \mathrm{G} 0$ compared with the control. Glyphosate-phosphorus interaction was significant (Table 4).

The protein content of leaves was not modified by different treatments and there was no interaction between them (Table 4).

\subsection{Cell Membrane Stability}

Glyphosate affected CMS at higher levels. P0G2 reduced CMS by about $20 \%$ and P0G3 by about $90 \%$, but there were no differences for P0G1 compared with the control. The percentage of CMS was not modified by phosphorus treatments, and there was no interaction between glyphosate and phosphorus (Table 4). 
Table 4. Effect of phosphorus and glyphosate addition to soil on chlorophyll and proteins contents and cell membrane stability (CMS) on Lotus corniculatus plants, 170 days after sowing

\begin{tabular}{lccc}
\hline Treatment* & $\begin{array}{c}\text { Chlorophyll } \\
\left(\mu \mathrm{g} \mathrm{cm}^{-2}\right)\end{array}$ & $\begin{array}{c}\text { Proteins } \\
\left(\mu \mathrm{g} \mathrm{cm}^{-2}\right)\end{array}$ & $\begin{array}{c}\text { CMS } \\
(\%)\end{array}$ \\
\hline P0 G0 & $425 \mathrm{c}$ & $6.4 \mathrm{a}$ & $100 \mathrm{a}$ \\
P0 G1 & $375 \mathrm{c}$ & $6.0 \mathrm{a}$ & $100 \mathrm{a}$ \\
P0 G2 & $200 \mathrm{~d}$ & $6.9 \mathrm{a}$ & $82 \mathrm{~b}$ \\
P0 G3 & $100 \mathrm{e}$ & $6.7 \mathrm{a}$ & $10 \mathrm{c}$ \\
& & & \\
P1 G0 & $600 \mathrm{~b}$ & $6.0 \mathrm{a}$ & $100 \mathrm{a}$ \\
P1 G1 & $400 \mathrm{c}$ & $6.5 \mathrm{a}$ & $100 \mathrm{a}$ \\
P1 G2 & $175 \mathrm{~d}$ & $6.5 \mathrm{a}$ & $87 \mathrm{~b}$ \\
P1 G3 & $100 \mathrm{e}$ & $6.9 \mathrm{a}$ & $8 \mathrm{c}$ \\
& & & \\
P2 G0 & $825 \mathrm{a}$ & $6.2 \mathrm{a}$ & $100 \mathrm{a}$ \\
P2 G1 & $450 \mathrm{c}$ & $6.5 \mathrm{a}$ & $100 \mathrm{a}$ \\
P2 G2 & $225 \mathrm{~d}$ & $6.4 \mathrm{a}$ & $82 \mathrm{~b}$ \\
P2 G3 & $100 \mathrm{e}$ & $6.6 \mathrm{a}$ & $9 \mathrm{c}$
\end{tabular}

Significance

$\begin{array}{llll}\mathrm{P} & * * & \mathrm{~ns} & \mathrm{~ns} \\ \mathrm{G} & * * & \mathrm{~ns} & * * \\ \mathrm{P} \times \mathrm{G} & * * & \mathrm{~ns} & \mathrm{Ns}\end{array}$

*P0G0, without incorporation of phosphorus and glyphosate; P0G1, without $\mathrm{P}+3.15 \mu \mathrm{M}$ glyphosate; P0G2, without $\mathrm{P}+6.32 \mu \mathrm{M}$ glyphosate; P0G3, without $\mathrm{P}+12.64 \mu \mathrm{M}$ glyphosate; P1G0, 100 ppm P without glyphosate: P1G1, 100 ppm P + 3.15 $\mu \mathrm{M}$ glyphosate; P1G2, 100 ppm P + $6.32 \mu \mathrm{M}$ glyphosate; P1G3, 100 ppm P $+12.64 \mu \mathrm{M}$ glyphosate; P2G0, 200 ppm P without glyphosate; P2G1, 200 ppm P + $3.15 \mu \mathrm{M}$ glyphosate; P2G2, 200 ppm P + 6.32 $\mu \mathrm{M}$ glyphosate; P2G3, 200 ppm P + $12.64 \mu \mathrm{M}$ glyphosate. Mean values followed by the same lower-case letter within each column are not significantly different $(P>0.05)$. ns, *, **: non-significant, or significant at $P \leq 0.05$ or 0.01 , respectively.

\section{Discussion}

Our findings provide evidence of the detrimental effect of glyphosate present in soil on the growth parameters of L. corniculatus, and show the existence of an interaction between glyphosate and soil phosphorus.

The mechanism by which glyphosate reduces the growth of plants is still unclear and does not appear to be the same in all cases (Fuchs et al., 2002). The effects of glyphosate on the EPSPS enzyme are known, but this inhibition affects other biochemical and physiological processes (Baylis, 2000), with differences among species such as Convolvulus arvensis (DeGennaro and Weller, 1984), Zea mays L. (Forlani \& Racchi, 1995), Lolium rigidum Gaudin (Lorraine-Colwill et al., 2001), and Capsicum anuum (Ronco et al., 2008).

In this study, glyphosate added to the soil affected both aerial and root growth, and both biochemical and physiological parameters. These results demonstrate glyphosate root uptake by L. corniculatus, in accordance with Rodrigues et al. (1982), who observed that glyphosate applied to wheat plants was absorbed by the roots of neighboring soybean plants through root contact, causing a reduction in the fresh weight and height of non-treated soybean plants. Moreover, Kaps and Kuhns (1987) observed that glyphosate molecules were transferred from Pinus ssp. to weeds by mycorrhizal hyphae.

When glyphosate is applied to leaves, it is transported throughout the plant by the phloem, affecting different metabolic pathways (Baylis, 2000). When added to the soil, it is absorbed by the roots and transported by xylem, as has been shown in the tomato (Cornish, 1992), soybean (Mujica et al., 1999), and pepper (Ronco et al., 2008). 
The primary detrimental effects of glyphosate on L. corniculatus appear to be localized at root level, as is the case with other species. The effects of glyphosate include root growth reduction, the inhibition of lateral root development, and an increase in necrotic root cells, which could reduce water and nutrient absorption significantly and cause damage by desiccation, as was observed by Pline et al. (2002) in cotton plants and by Ronco et al (2008) in pepper plants. They also observed reductions in RDW and lateral root elongation in plants subjected to glyphosate concentrations of $0.01 \mathrm{mM}$ (or greater). Meanwhile, the connections between lateral roots and the main root in soybean and in pepper plants grown without glyphosate were intact and functional (Torres et al., 2003; Ronco et al., 2008).

Several factors may bring about the reduction in aerial growth in L. corniculatus plants subjected to different levels of phosphorus and glyphosate in this study. As expressed above, there is a reduction in the plant's water absorption capacity due to root damage by glyphosate. The incorporation of the herbicide into the xylem flow and its transportation to aerial parts of the plant affect aerial growth, as was observed in soybean plants by Mujica et al. (1999). On the other hand, the growth parameter results — such as ADW and leaf area - observed in L. corniculatus plants treated with high levels of phosphorus would allow to infer soil glyphosate desorption due to competition from phosphate ions. This is in agreement with the findings of Ronco et al. (2008) for pepper plants and Cornish (1992) for tomato plants grown with high levels of phosphorus in the soil.

The effect of phosphorus on plant height and the length of regrowth in L. corniculatus is in keeping with the findings of other authors. Although it is well known that phosphorus fertilization improves the competitive ability of legumes, Lotus spp. has demonstrated a greater response to lower doses than other legume species (Castaño \& Miñon, 1990; Mazzanti et al., 1988; Cahuepé et al., 1982). With regard to phosphorus fertilization in soils analogous to that of this experiment, L. corniculatus showed a greater increase in dry matter than Trifolium pratense to low rates of phosphorus, (Ayala Torales et al., 1992).

Glyphosate also appears to have detrimental effects on other variables such as chlorophyll content and cell membrane damage. The reduction in chlorophyll content in L. corniculatus as a result of the application of glyphosate and high levels of phosphorus is in accordance with the results of Ronco et al. (2008) for pepper plants, who observed lower chlorophyll content in plants grown at high phosphorus levels and with mean glyphosate doses.

In terms of cell membrane damage, there is insufficient information about the effects of glyphosate on this. Plant cell membranes are sensitive to environmental stress (Steponkus, 1984), which increases cell membrane permeability, their disorganization, electrolyte leakage, leading to a reduction in the photosynthetic capacity of plant tissues (Campos et al., 2003; Beltrano \& Ronco, 2008; Dubey, 1997). Cell damage can be estimated by comparing the conductivity in water of the solutes leaked from injured and uninjured tissues (Mattsson, 1996; McNabb \& Takahashi, 2000; Beltrano \& Ronco, 2008). The membrane damage by glyphosate observed in $L$. corniculatus appears similar to other abiotic stress effects and may constitute another deleterious mechanism of glyphosate.

The results of glyphosate-phosphorus interaction could be attributed to the physical and chemical features of the soil used in this experiment. The relationship between glyphosate adsorption and the soil's phosphorus adsorption capacity is clear in the literature (Hance, 1976; Glass, 1987; Miles \& Moye, 1988; Gerritse et al., 1996; Bott et al., 2011) and is probably related to specific phosphorus adsorption mechanisms in the soil, namely the covalent bonds between oxygen from a phosphate and metal from an oxide. Thus, the methylphosphonic group of glyphosate may compete with inorganic phosphates for soil adsorption sites.

Prata et al. (2000) report that glyphosate adsorption in three different soils was influenced by the levels of phosphorus in the soil. The amount of glyphosate adsorbed was substantially reduced at phosphorus levels starting from $770 \mathrm{ppm}$. This reduction in glyphosate adsorption, however, would have no practical importance since these phosphorus levels would never be reached under field conditions in agricultural soils. This suggests that under these conditions, the competition between glyphosate and phosphorus for covalent binding sites in the soil must not occur (Prata et al., 2000).In this study the lower glyphosate adsorption seems to take place at lower phosphorus levels in the soil, to an order of $100 \mathrm{ppm}$. These differences could be attributed to the fact that the relationship between glyphosate adsorption and the levels of phosphorus in the soil is also influenced by other factors. Several works describe how glyphosate adsorption by soils or clays depends on $\mathrm{pH}$ (Nomura and Hilton, 1977); cation exchange capacity (CEC); the presence of iron and aluminum amorphous oxides and organic matter (Morillo et al., 2000; Bott et al., 2011); and that of iron and aluminum oxides (Gerritse et al., 1996; Prata et al., 2000). 
However, there is no agreement about the most important factors controlling glyphosate adsorption and the competitive adsorption between glyphosate and phosphorus in soil. It was also observed that the amount of glyphosate adsorbed by soils decreased when $\mathrm{pH}$ was increased from 4 to 7 (Cruz et al., 2007). This could be attributed to the fact that an increase in the negative charge of the soil surface could weaken the interaction between this and glyphosate (McConnell \& Hossner, 1985).

The studies of competitive adsorption between phosphate ion and glyphosate in clay minerals and soils have shown that glyphosate can be displaced by phosphate (McBride \& Kung, 1989; Dion et al., 2001; Gimsing \& Boggaard, 2001; Bott et al., 2011). The displacement of glyphosate by phosphate can occur easily in some minerals such as amorphous iron oxide and goethite (McBride \& Kung, 1989; Gimsing \& Boggaard, 2001), but is affected by different factors in clays and agricultural soils (Dion et al., 2001).

Several authors studying the effect of $\mathrm{pH}$ and clay types on the adsorption of glyphosate by soils agreed that an increase in $\mathrm{pH}$ decreased glyphosate adsorption, which was related to soil surface areas, in that montmorillonite has lower glyphosate adsorption levels than bentonite and kaolinite (Cruz et al., 2007).

The features of the soil used in this experiment-a vertic argiudoll with a $\mathrm{pH}$ of 5.5, coupled with the presence of clays such as montmorillonite (27\%), and a high CEC (to the order of 32 meq. $100 \mathrm{~g}^{-1}$ ) - could result in lower glyphosate adsorption in comparison to more acidic or alkaline soils where this type of clay is present, as was observed by Cruz et al. (2007). Thus, soil features could cause relatively low glyphosate retention capacity, leading to high herbicide content in the soil solution and a greater deleterious effect on the growth of $L$. corniculatus plants, as observed in this study.

Phosphorus adsorption depends on the physical and chemical features of the soil. The regulatory phosphorus capacity of soil, defined by Beckett and White (1964), is related to; clay content (Fox \& Kamprath, 1970); pH (Parfitt, 1977; Holford \& Patrick, 1979); and organic matter (Bolaño et al., 1984). A low regulatory phosphorus capacity implies that the soil has a weak capacity for retaining available phosphorus, be it natural or added as fertilizer, and phosphorus reserves within it are rapidly depleted.

As the experimental soil had a medium to high regulatory phosphorus capacity value, $33.52 \mathrm{mg} \mathrm{P} \mathrm{Kg}^{-1}$ soil (Bolaño et al., 1984), increased phosphorus adsorption by the soil would displace glyphosate binding sites, leading to greater glyphosate desorption and a greater availability of herbicide for root uptake.

This effect could be due to the increased capacity of the organic fraction of soil as phosphorus adsorption site and the secondary role of this fraction for glyphosate adsorption (Prata et al., 2000), besides low presence of iron and aluminum amorphous oxides in the experimental soil, that have greater affinity for adsorption of glyphosate (Rajan, 1973).

With regard to secondary experimental evidence, the findings of this study show that the deleterious effects of glyphosate were maintained throughout the entire experiment (170 days), and confirm that the degradation of glyphosate by light and microorganism not seem to be significant, in agreement with Nomura and Hilton (1977), who observed that the half-life of glyphosate varied from several months to years.

\section{Conclusion}

In conclusion, in accordance with Bott et al. (2011) and da Cruz et. al. (2007), the results of this study suggest that in cropping systems with limited soil disturbance, as no-till agriculture, the remobilization of glyphosate residues in soils through the addition of phosphate fertilizers, should be considered a serious problem for succedaneous crops and non target plant.

\section{Acknowledgment}

To L. Wanhan (CONICET) for technical and analytical assistance and to the Universidad Nacional de La Plata and CIC-PBA for financial support. J. Beltrano is researcher of CIC-PBA.

\section{References}

Agnusdei, M. (1991). Análisis de gradiente de vegetación, suelo y uso en pastizales de áreas bajas de la depresión del Salado. Tesis M Sc. Facultad de Ciencias Agrarias, UNMdP.

Ayala Torales, A., Acosta, G., Deregibus, V., \& Cabrini, S. (1992). Efectos de la modalidad de defoliación y de la fertilización fosforada en pasturas integradas por Lotus corniculatus L. Revista Argentina de Producción Animal, 15(1), 77-80. 
Ayala Torales, A., Acosta, G. \& Deregibus, V. (1992b). Efectos de la modalidad de defoliación y de la fertilización fosforada en pasturas integradas por Lotus corniculatus. Calidad y producción de materia seca digestible. Revista Argentina de Producción Animal, 15(1), 80-83.

Baylis, A. D. (2000). Why glyphosate is a global herbicide: strengths, weaknesses and prospects. Pesticide Management Science, 56, 299-308. http://dx.doi.org/10.1002/(SICI)1526-4998 (200004)

Beckett, P. H. T., \& White, R. E. (1964). Studies on the phosphate potentials on soils. Plant and Soil, 3, 253-282.

Beltrano, J., \& Ronco, M. G. (2008). Improved tolerance to wheat plants (Triticum aestivum L.) to drought stress and rewatering by the arbuscular mycorrhizal fungus Glomus claroideum: Effect on growth and cell membrane stability. Brazilian Journal of Plant Physiology, 20(1), 29-37. http://dx.doi.org/10.1590/S1677-04202008000100004

Beuselinck, P. R., \& Grant, W. F. (1995). Birdsfoot trefoil. Forages and Introduction to Grassland Agriculture, $1,237-248$.

Blackburn, L., \& Boutin, C. (2003). Subtle effects of herbicide use in the context of genetically modified crops: a case study with glyphosate. Ecotoxicology, 12, 271-285. http://dx.doi.org/ 10.1023/A:1022515129526

Bolaño, A. (1984). Determinación de la capacidad reguladora y concentración ajustada de fósforo, en suelos de la región pampeana. Ciencia del Suelo, 2(1), 99-106.

Bott, S., Tesfamariam, T., Kania, A., Eman, B., Aslan, N., Roemheld, V., \& Neumann, G. (2011). Phytotoxicity of glyphosate soil residues re-mobilised by phosphate fertilization. Plant Soil, 315, 2-11. http://dx.doi.org/10.1007/s11104-010-06989-3

Bradford, M. M. (1976). A rapid and sensitive method for the quantitation of microgram quantities of protein utilizing the principle of protein-dye binding. Annals of Biochemistry, 72, 248-254.

Busse, M. D., Ratcliff, A. W., Shestak, C. J., \& Powers, R. F. (2001). Glyphosate toxicity and the effects of long-term vegetation control on soil microbial communities. Soil Biology and Biochemistry, 33, 1777-1789. http://dx.doi.org/10-1016/S0038-0717(01)00103-1

Campos, P. S., Quartin, V., Ramalho, J. C., \& Nunes, M. A. (2003). Electrolyte leakage and lipid degradation account for cold sensitivity in leaves of Coffea sp. plants. Journal of Plant Physiology, 160, 283-292. http://dx.doi.org/0176-1617/03/160/03-283

Castaño, J., \& Miñon, V. D. (1990). Respuesta al agregado de fósforo de Lotus tenuis y Lotus corniculatus. Revista Argentina de Producción Animal, 10(1), 30-31.

Cauhepe, M., Ridruejo, E., \& Aldea, O. (1982). Intersiembra y fertilización en cobertura como métodos alternativos de modificación de los pastizales de la Depresión del Salado. Revista Argentina de Producción Animal, 2, 510-518.

Cornish, P. S. (1992). Glyphosate residues in sandy soil affect tomato transplants. Australian Journal of Experimental Agriculture, 32, 395-399.

Cruz, L. H., Santana, H., Vieira Zaia, C. T. B., \& Morozin Zaia, D. M. (2007). Adsorption of glyphosate on clays and soils from Paraná State: Effect of $\mathrm{pH}$ and competitive adsorption of phosphate. Brazilian Archives of Biology and Technology, 50(3), 385-394.

De Gennaro, F. P., \& Weller, S. C. (1984). Differential susceptibility of field bindweed (Convolvulus arvensis) biotypes to glyphosate. Weed Science, 32, 472-476.

De Jonge, H. L., De Jonge, W., Jacobsen, O. H., Yamaguchi, T., \& Moldrup, P. (2001). Glyphosate sorption in soils of differentes $\mathrm{pH}$ and phosphorus content. Soil Science, 166, 230-238.

Dion, H. M., Harsh, J. B., \& Hill, H. H. (2001). Competitive sorption between glyphosate and inorganic phosphate on clay minerals and low organic matter soils. Journal of Radioanalysis and Nuclear Chemistry, 249, 385-390.

Dubey, R. S. (1997). Photosynthesis in plants under stressful conditions. In M. Pessarakli (Ed), Handbook of Photosynthesis (pp. 859-875). Marcel Dekker, New York.

Forlani, G., \& Racchi, L. M. (1995). Glyphosate tolerance in maize (Zea mays L.). 1. Differential response among inbred lines. Euphytica, 82, 157-164. 
Fox, R. L., \& Kamprath, E. J. (1970). Phosphate sorption isotherms for evaluating the phosphate requirements of soils. Soil Science Society of America Proceedings, 34, 902-907.

Fuchs, M. A., Geiger, D. R., Reynolds, T. L., \& Bourque, J. E. (2002). Mechanisms of glyphosate toxicity in velvetleaf (Abutilon theophrasti). Pesticide and Biochemistry Physiology, 74, 27-39. http://dx.doi.org/:10.1016/S0048-3575(02)00118-9

Gerritse, R. G., Beltran, J., \& Hernandez, F. (1996). Adsorption of atrazine, simazine, and glyphosate in soils of the Gnangara Mound, Western Australia. Australian Journal of Soil Research, 34, 599-607. http://dx.doi.org/10.1071/SR9960599

Gimsing, A. L., \& Borgaard, O. K. (2001). Effect of $\mathrm{KCl}$ and $\mathrm{CaCl}_{2}$ as background electrolytes on the competitive adsorption of glyphosate and phosphate on goethite. Clays and Clay Minerals, 49, 270-275.

Gimsing, A. L., \& Borgaard, O. K. (2002). Effect of Phosphate on the Adsorption of Glyphosate on Soils, Clay Minerals and Oxides. International Journal of Environmental Analytical Chemistry, 82, 545-552.

Gimsing, A. L., Borgaard, O. K., \& Bang, M. (2004). Influence of soil composition on adsorption of glyphosate and phosphate by contrasting anish surface soils. European Journal of Soil Science, 55(1), 183-191. http://dx.doi.org/: 10.1046/j.1365-2389.2003.00585.x

Glass, R. L. (1987). Adsorption of glyphosate by soils and clay minerals. Journal of Agriculture and Food Chemistry, 35, 497-500.

Grossbard, E., \& Atkinson, D. (1985). The Herbicide Glyphosate. Cambridge, UK.: Butterworth-Heinemann, Ltd.

Hance, R. J. (1976). Adsorption of glyphosate by soils. Pesticide Science, 7, 363-366.

Holford, I. C. R., \& Patrick, N. (1979). Effects of reduction and pH changes on phosphate sorption and mobility in an acid soil. Soil Science Society of America Journal, 43, 292-297.

Kaps, M. A., \& Kuhns, L. J. (1987). Glyphosate transfer between plants via mycorrhizal fungi. HortScience, 22, $11-28$.

Kurincic, E., Martin, G., Lagler, J. C., Spinosa, M., \& Scopetta, N. (2002, October). Intersiembra de Lotus corniculatus en un pastizal natural tratado con glifosato. Paper presented at the $25^{\circ}$ Congreso Argentino de Producción Animal. Asociación Argentina de Producción Animal (AAPA), Buenos Aires, Argentina.

Leon, R. J. C., \& Bertiller, S. (1982). Aspectos fenológicos de dos comunidades de un pastizal de la Depresión del Salado (provincia de Buenos Aires). Boletin de la Sociedad Argentina de Botanica, 20(3-4), 329-347.

Lorraine-Colwill, D. F., Powles, S. B., Hawkes, T. R., \& Preston, C. (2001). Inheritance of evolved glyphosate resistance in Lolium rigidum (Gaud.). Theoretical and Applied Genetic, 102, 545-550.

Mattsson, A. (1996). Predicting field performance using seedling quality assessment. New Forests, 13, 223-248.

Mazzanti, A., Montes, L., Miñon, D., Sarlangue, H., \& Cheppi, C. (1988). Utilización del Lotus tenuis en establecimientos ganaderos de la Pampa Deprimida: resultados de una encuesta. Revista Argentina de Producción Animal, 8(5), 357-376.

Mc Bride, M., \& Kung, K. H. (1989). Complexation of glyphosate and related ligands with iron (III). Soil Science Society of America Journal, 53, 1668-1673.

Mc Connell, J.S. \& Hossner, L. R. (1985). pH Dependent adsorption isotherms of Glyphosate. Journal of Agriculture and Food Chemistry, 33, 1075-1078.

Mc Nabb, K., \& Takahashi, E. (2000). Freeze damage to loblolly pine seedlings as indicated by conductivity measurements and outplanting survival. Auburn University Southern Forest Nursery Management Cooperative. Research Report, 00-4.

Milles, C. J., \& Moye, H. A. (1988). Extraction of glyphosate herbicide from soil and clay minerals and determination of residues in soils. Journal of Agriculture and Food Chemistry, 36, 486-491.

Morillo, E., Undabeytia, T., Maqueda, C., \& Ramos, A. (2000). Glyphosate adsorption on soils of different characteristics. Influence of copper addition. Chemosphere, 40, 103-107.

Moran, R., \& Porath, D. (1980). Chlorophyll determination in intact tissues using N,N-dimethylformamide. Plant Physiology, 65, 478-479. 
Mujica, M., Fracchia, S., Ocampo, J., \& Godeas, A. (1999). Influence of the herbicides chlorsulfuron and glyphosate on mycorrhizal soybean intercropped with the weeds Brassica campestris or Sorghum halepense. Symbiosis, 27, 73-81.

Neumann, G., Kohl, S., Landsberg, K., Stock-Oliveira Souza, K., Yamada, T., \& Romeheld, V. (2006). Relevance of glyphosate transfer to non-target plants via the rhizosphere. Journal of Plant Disease Protection, 20, 963-970.

Nomura, N. S., \& Hilton, H. W. (1977). The adsorption and degradation of glyphosate in five Hawaiian sugarcane soils. Weed Research, 17, 113-121.

Parfitt, R. L. (1977). Phosphate adsorption on an oxisol. Soil Science Society of America Proceedings, 41, 1064-1067.

Pengue, W. A. (2000). Cultivos transgénicos ¿Hacia dónde vamos?. Buenos Aires. Editorial Lugar.

Piccolo, A., Celano, G., Arienzo, M., \& Mirabella, A. (1994). Adsorption and desorption of glyphosate in some European soils. Journal of Environmental and Science Health, 6, 1105-1115.

Pline, W. A., Wilcut, J. W., Edmisten, K. L., \& Wells, R. (2002). Physiological and morphological response of glyphosate-resistant and non-glyphosate-resistant cotton seedlings to rootabsorbed glyphosate. Pesticide Biochemistry and Physiology, 73, 48-58.

Prata, F., Lavorenti, A., Regitano, J. B., \& Tornisielo, V. L. (2000). Influência da matéria orgânica na sorção e dessorção do glifosato em solos com diferentes atributos mineralógicos. Revista Brasileira do Ciência do Solo, 24, 947-951.

Rajan, S. S. (1973). Phosphorus adsorption characteristics of Hawaian soils and their relationship to equilibrium phosphorus concentration required for growth of millet. Plant and Soil, 39, 519-532.

Rodrigues, J. J. V., Worsham, A. D., \& Corbin, F. T. (1982). Exudation of glyphosate from wheat (Triticum aestivum) plants and its effects on interplanted corn (Zea mays) and soybeans (Glycine max). Weed Science, 30, 316-320.

Ronco, M. G., Beltrano, J., Ruscitti, M., \& Arango, M. C. (2008). Glyphosate and mycorrhization induce changes in plant growth and in root morphology and architecture in pepper plants (Capsicum annuum L.). Journal of Horticultural Science and Biotechnology, 83(4), 497-505.

Rueppel, M. L., Brightwell, B. B., Schaefer, J., \& Marvell, J. T. (1977). Metabolism and degradation of glyphosate in soil and water. Journal of Agriculture and Food Chemistry, 25, 517-528.

Steponkus, P. L. (1984). Role of the plasma membrane in freezing injury and cold acclimation. Annual Review of Plant Physiology, 35, 543-584.

Sullivan, C., \& Ross, W. M. (1979). Selecting for drought and heat resistance sorghum. In: H. Mussell and T. Taples (Eds), Stress physiology in crops plants (pp. 264-281). John Willey and Sons, USA.

Torres, C., Marco Nascimento, W., Vasconcelos Paiva, S. A., \& Souza de Aragão, F. A. (2003). Bioassay for detection of transgenic soybean seeds tolerant to glyphosate. Pesquiza Agropecuaria Brasileira, 38, 1053-1057. 